\title{
Julian of Norwich and Her Children Today: Editions, Translations and Versions of Her Revelations
}

\begin{abstract}
Alexandra Barratt
The viability of such concepts as "authorial intention," "the original text," "critical edition" and, above all, "scholarly editorial objectivity" is not what it was, and a study of the textual progeny of the revelations of Julian of Norwich--editions, versions, translations and selections--does little to rehabilitate them. Rather it tends to support the view that a history of reading is indeed a history of misreading or, more positively, that texts can have an organic life of their own that allows them to reproduce and evolve quite independently of their author. Julian's texts have had a more robustly continuous life than those of any other Middle English mystic. Their history--in manuscript and print, in editions more or less approximating Middle English and in translations more or less approaching Modern English--is virtually unbroken since the fifteenth century. But on this perilous journey, many and strange are the clutches into which she and her textual progeny have fallen.
\end{abstract}

The earliest version of the revelations is the unique copy of the Short Text in London, BL MS Additional 37790. This copy was made sometime after 1435 from an exemplar dated 1413, as we know from its opening, which refers to Julian as still 
alive in that year. ${ }^{1}$ The Carthusian monks, who also preserved the unique manuscript copy of The Book of Margery Kempe, must be credited with its preservation. ${ }^{2}$ The only other pre-Reformation Julian manuscript, dated around 1500, is now London, Westminster Treasury MS 4, in the Westminster Archdiocesan Archives; it contains selections from the Long Text combined with selections from Walter Hilton. ${ }^{3}$ But the only complete manuscripts of the Long Text are post-Reformation, and this fact poses particular problems for the establishment of the text. The seventeenth-century Paris Manuscript (Paris, BnF anglais 40) is already to a certain extent a "modernization," as it has substituted then-current words for those that were already obsolete. Opinions as to its exact date still vary, ${ }^{4}$ but there is no doubt that it is Benedictine and probably belonged to the monastery of exiled English Benedictine nuns in Paris.

There is rather more consensus about the date of the Sloane Manuscript (London, BL MS Sloane 2499), the only other independent witness to the Long Text, though not about its textual value. Dated as around 1650, it is written in a hand that resembles that of Anne Clementine Cary, a Paris Benedictine nun who died in $1671 .{ }^{5}$ Marion Glasscoe argues that this manuscript is early seventeenth-century and was intended as "a faithful copy of an earlier version,"6 and is not alone in holding that it largely preserves the distinctively Middle English features of the original language. It is, therefore, more of an "edition" and less of a "translation" than the Paris Manuscript.

In 1670 the first printed edition of either Julian text appeared, as XVI revelations of divine love, shewed to a devout servant of our Lord, called Mother Juliana, an anchorete of 
Norwich: who lived in the dayes of King Edward the Third. This was edited, probably from the Paris Manuscript, by Serenus Cressy, an English convert to Roman Catholicism who had become a Benedictine monk. In 1651 the Benedictine congregation had directed him "to accompany nuns from Cambrai to a new foundation in Paris, where he acted for a year as chaplain." 7 In his address "To the Reader," for the first time someone responsible for transmitting a Julian text left a record of his "editorial" policy:

I conceived it would have been a prejudice to the agreeable simplicity of the Stile, to have changed the Dress of it into our Modern Language, as some advised. Yet certain more out of fashion, Words or Phrases, I thought meet to explain in the Margine. ${ }^{8}$

Most of these marginal glosses are accurate enough, though some, e.g. "mind" for feeling, "earnest" for wilful, "friendly" for homelie, "confessarius" for domesman, have an air of guesswork. Cressy had in fact hit upon the very method followed by so many subsequent "modernizers" of Julian's texts: he glosses or (sometime) replaces obviously obsolete individual words but otherwise simply modernizes the spelling of words that appear to be still current. Unfortunately, many Middle English words that survive into Modern English have changed their meanings radically and significantly. These "false friends," to use C. S. Lewis's phrase, include such common but structurally essential words as can, wold (i.e. 'would'), shal and may, and other 
more technical words vital to Julian's thought such as (notoriously) substance and sensualite.

Once there is a printed edition of a text as well as manuscript witnesses, the history of reading and misreading becomes more complex. The Upholland Manuscript,${ }^{9}$ written by various English Benedictine Cambrai nuns in the mid- to late-seventeenth century, contains selections from the Long Text, but these were probably copied from Cressy's printed edition rather than from an earlier manuscript. In the next century another manuscript version (now London, BL MS Sloane 3705) was made. This was a modernized copy of Sloane 2499 which had been collated with either the Paris Manuscript or Cressy's edition and included some of their readings.

Until the nineteenth century, then, Julian's Long Text circulated only among English Catholics, and her Short Text was not known at all. Only two copies of Cressy's printed edition were listed in the original Short Title Catalogue, though the on-line ESTC now lists copies in eleven British libraries, plus one in Berlin, and three in the United States. Colledge and Walsh credit Julian's survival to Father Augustine Baker, but perhaps the nuns of Paris and Cambrai, who provided the manual labor at least to copy the manuscripts, deserve some acknowledgment too.

In the nineteenth century the Long Text began to reach a wider public. George Hargreave Parker, an Anglican priest, reissued Cressy's edition in 1843, writing in his introduction: 
The work is printed verbatim and literatim from the edition of 1670, except in one or two instances where a typographical error was obvious. ${ }^{10}$

This is not quite true. Parker also modernized, or rather regularized to nineteenthcentury usage, Cressy's use of capital letters, and removed Cressy's glosses from the margins, gathering them together at the end of the text to form a "glossary of obsolete words and phrases," as he describes it. But he mainly reproduced Cressy's punctuation and paragraphing and tried to give a typographic equivalent of the original ornamentation. He also kept at least two glaring errors in the text itself. In Chapter 7, in the passage that describes the drops of blood flowing down Christ's face, Cressy had printed, "And for the roundness, they were like to the Seal of her Ring." He was followed uncritically by Parker. Both the Paris and Sloane Manuscripts, of course, have the correct though perhaps more unexpected phrase "scale of heryng." Similarly, in Chapter 10 Parker followed Cressy in printing, "One time my understanding was litle down into the sea-ground", where the Paris Manuscript reads, "One tyme my vnderstandyng was lett down in to the seagrounde" and Sloane reads led for lett. Parker, unlike some later editors, had apparently no gift, or desire, for conjectural emendation.

The main interest of Parker's edition, however, is its motivation. Why should a Victorian Anglican clergyman go to the trouble of reprinting a rather rare Recusant edition of an obscure medieval text? Apparently he saw Julian as an Anglican born before her time: in his introduction he writes that her text 
confirms our belief that even during the worst corruptions of the Romish Church there was a generation within its pale who ... formed a part of that vital bond which connected the Apostolic Church with the revival of primitive Christianity at the time of the Reformation. It is very interesting to trace the strugglings of the writer's mind against pre-conceived and erroneous opinions.

Otherwise, Julian gains only cautious and qualified approval:

The spiritually-minded reader will meet with some few statements in the course of the following pages, with which he will not be able to acquiesce; but in the main he will meet with much amply to repay a careful perusal. ${ }^{11}$

In contrast to the enthusiasm lavished on Julian since the beginning of the twentieth century, his overall assessment of her is somewhat refreshing: "The matter is peculiar; the style quaint; and the language obscure."12

Not much information is available about Parker. He was vicar of a parish in Bethnal Green, in the slums of London. His other publications were an edition of a treatise by John Eaton (1575-1641), strongly Protestant in its theology, and a pamphlet, Letters on the Great Revolution of 1848, in which he argued that the liberal revolutions that occurred throughout Europe in that year were master-minded by the 
Pope as a plot to bring all of the continent under his sway. The only cohesive factor to all three publications, then, seems to be a strong anti-Roman Catholicism.

Some fifty years later, in 1877, the first printed edition based on the Sloane Manuscript, rather than (directly or indirectly) on the Paris Manuscript, appeared. Henry Collins, an Anglican convert to Roman Catholicism, edited it as Revelations of Divine Love. Twenty years earlier he had published Difficulties of A Convert from The Anglican to the Catholic Church, in which he had appealed to his newly-acquired coreligionists to treat potential converts with slightly more tact: "kind and gentle dealings with Anglicans is the only prevailing way of softening their prejudices, explicating their difficulties, and otherwise preparing a road for complete reunion." One can easily see the appeal of Julian's text to someone with such anachronistically irenic ecumenical attitudes.

Collins was a serious and reputable scholar. His edition of Julian was merely one of numerous spiritual classics that he edited and translated over the years. But his edition of the Sloane Manuscript is not all that he claimed. Although he called his publication an "edition," it is really a "modernization": as he explained:

The antique spelling has been laid aside as unintelligible to all but the learned, and some few words have been translated to render the sense intelligible. A list of such words appears at the end of this preface. With all this the ordinary reader will find sufficient difficulty in mastering the meaning of many passages. ${ }^{13}$ 
Furthermore, although he did appreciate that "[t]he MS on which the present edition is formed, differs from that followed by Cressy, both in the division of chapters, and in various readings, 14 he judged none of these differences very important and in fact he relied far more on Cressy's printed edition than he was willing to admit. My own comparison of a sample of the text did not produce a single indisputable instance where he had followed the Sloane Manuscript reading rather than Cressy's on occasions on which they diverged.

Collins did however print the chapter-headings found in the Sloane Manuscript and mainly followed the Sloane rather than Cressy chapter-divisions. Strangely, although he printed the opening of the final passage (thought to be a scribal addition) peculiar to the Sloane Manuscript, beginning "Thus endith the revelation of love," his text stops with the sentence "I pray almighty God that this book come not but to the hands of them that will be his faithful lovers, and to those that will submit them to the faith of Holy Church," although the manuscript itself continues for another half-page. Ironically, the passage omitted includes the sentence, “And beware that thou take not on thing after thy affection and liking and leve another, for that is the condition of an heretique," but it is hard to account for this omission other than by sheer carelessness.

Probably Collins genuinely believed that the differences between the Sloane Manuscript and the Cressy edition were insignificant. He spotted something as obvious as the chapter-headings and incorporated them into his version but he was 
no doubt working fast (by modern editorial standards) and, impatient with the relative illegibility of the Sloane Manuscript, relied heavily on Cressy. Nor should we criticize him too harshly for this. The study of English Literature was only just beginning to establish itself as a serious academic discipline and there was as yet no "canon" of Middle English prose texts that had to be treated with accuracy and respect. The interest in Julian came, not from academics, but from more and more devout Catholics (Anglican and Roman) who were intrigued or inspired by what Julian had to say--or rather, by what they were led to think she had said.

In 1901 Grace Warrack's version, Revelations of Divine Love, appeared. This went through many editions over the next fifty or sixty years, a reprint of the thirteenth appearing as recently as 1958. (It was here that I, like many other students in the 1960s, first encountered Julian.) Warrack knew of the Paris Manuscript as well as Cressy's printed edition but preferred to base her version (her own word) on the Sloane Manuscript. She does not seem to have regarded this as more than a matter of convenience, however, for she wrote of Cressy's edition, "It agrees with the Manuscript now in Paris, but the readings that differ from the Sloane Manuscript are very few and are quite unimportant."15

Her statement of her editorial practice is comprehensive, honest and informative: 
For the following version, the editor having transcribed the Sloane MS., divided its continuous lines into paragraphs, supplied to many words capital letters, and while following as far as possible the significance of the commas and occasional full stops of the original, endeavoured to make the meaning clearer by a more varied punctuation. As the book is designed for general use, modern spelling has been adopted, and most words entirely obsolete in speech have been rendered in modem English, though a few that seemed of special significance or charm have been retained. ${ }^{16}$

She is aware of the potential hazards this policy entails, however, and in Chapter 58, for instance, although she keeps "Substance" for ME substance, substitutes an invented term, "Sense-part," for sensualite and does not merely "modernize" it to "sensuality". Her "rule of never omitting a word from the Manuscript, and of enclosing within square brackets the very words added"17 sometimes makes for awkward reading but at least avoids the destruction of evidence. In practical terms her version was a great success and enjoyed a steady sale; unfortunately it still lives on in a way that Warrack herself would surely have deplored, being used by some recent popular versions as a substitute for the Sloane Manuscript itself.

In 1902 a rather different version of Julian appeared. The Jesuit priest George Tyrrell reprinted--yet again--Cressy's 1670 edition, stating in a final note: 
That edition has been followed faithfully, except in a few cases where obvious misprints, or the spelling, seemed likely to lead to confusion for the reader. ${ }^{18}$

(He also altered Cressy's punctuation "wherever it seemed needful.") Tyrrell, unlike Parker, did suggest some emendations, which he put in square brackets rather than incorporating into the text: in Chapter 7 he prints "the seal [scale] of herring," and in Chapter 10 "my understanding was litle [?led] down into the sea-ground," both changes that suggest he had consulted the Sloane Manuscript, the existence of which he knew.

But the real interest of this edition is not textual. Tyrrell (1861-1909) ${ }^{19}$ was a leading figure in the Catholic Modernist movement. Anglo-Irish by birth, he was brought up as an evangelical Anglican but became a Roman Catholic at the age of 18 . He joined the Society of Jesus and was ordained priest in 1891. Intellectually brilliant, he became renowned as a spiritual director, retreat conductor and writer, and was a friend of Baron Von Hügel, author of The Mystical Element of Religion. But in 1899 he published an article, entitled "A Perverted Doctrine," on the doctrine of eternal suffering, which incurred the displeasure of the Jesuit censors at Rome. According to his friend and biographer Maud Petre, this article was inspired by his reading of Julian. From 1900 he was effectively exiled to a remote parish in Yorkshire until dismissed by the Jesuits in 1906. In the following year he was excommunicated and two years later he died and was buried in an Anglican cemetery. 
Tyrrell's introduction to the Cressy reprint hints at his own position in 1902. He saw himself reflected in a Julian tormented by those very aspects of Catholic teaching on damnation that caused him distress. Of her treatment of the problem of predestination he wrote:

It is curious and instructive to see how, in many ways, Mother Juliana's spirit of Catholic-hearted love was cramped in its efforts at self-expression by certain current theological conceptions of the time, whose subsequent Calvinistic developments caused them, even in their more tolerable forms, to be eventually abandoned by the Church. ${ }^{20}$

While Parker had seen Julian as a proto-Protestant and Collins as an early ecumenist, Tyrrell saw her as a fellow Catholic Modernist. This version was eventually reprinted but not until 1920, by which time Warrack's more successful version had reached its seventh edition.

Meanwhile, back at the British Museum there had been an exciting new development: the Short Text, known to the historian Francis Blomefield in the eighteenth century, ${ }^{21}$ had been rediscovered when in 1909 the Museum purchased the Amherst Manuscript (now MS Add. 37790). Two years later a version was published by Dundas Harford, whose policy was described as follows: 
The Editor has tried to give the original wording, wherever it would not be positively misleading to the modern reader. He has modernised the spelling. For the punctuation, and the division into paragraphs, he is alone responsible, as there are few stops, and no breaks, in the MS.22

Harford also invented chapter headings and a title, Comfortable Words to Christ's Lovers, which survived the first two editions but was eventually replaced by The Shewings of the Lady Julian.

Harford (1858-1953) was an Anglican priest and Vicar of St Stephen's, Norwich, between 1901 and 1908. Possibly the Norwich connection was the reason he was chosen to edit the newly-found text. He was the first to argue that the Short Text was Julian's original account of her experiences, which she expanded fifteen years later into the Long Text. This hypothesis has been generally accepted except by Julian Bolton Holloway, whose views on all the Julian manuscripts, their dates and their inter-relationships, are often different from those of other scholars. ${ }^{23}$

It was in the early twentieth century, too, that the dismemberment of Julian, and her reconstitution in the more palatable form of extracts and selections, began-or rather, continued and gathered strength, as both the Westminster and Upholland manuscripts had long ago ignored the stern warnings of the Sloane scribe against incomplete transmission. In 1908 an anonymous collection, All Shall Be Well (the first of numerous books with this title), was issued. This claimed to extract from Warrack's version 
those few pearls of spiritual thought, hoping that some who are hindered by the lack of time or opportunity or by difficulty of style and language, from giving this wonderful book the study it deserves, may find in them helpful subjects for meditation and prayer. ${ }^{24}$

The compiler also carried a torch for the restoration of the solitary life in the Church of England, murmuring wistfully:

Have we no place in our twentieth century for such as Julian? Are there none whose souls are athirst for God, who are unsuited for a life in Community, unfitted for the ceaseless round of active life which seems unavoidable in our large English sisterhoods, who yet would gladly answer the call to a life of seclusion, devoted to prayer and meditation?25

A few years later appeared The Shewing of a Vision, once again extracts from Warrack's version, compiled by an Anglican sister with a preface by George Congreve S.S.J.E. The tone may be adequately judged by this sample from the preface to the "priceless little book" by "this beautiful character": 
In every page one meets charming tokens of English education and character, traces of love of home, of religion that made her childhood and youth happy, traces of poetic insight, of humour, of happy laughter.... ${ }^{26}$

This marks the one and only appearance of Julian as the Georgian Country Gentlewoman.

Julian was becoming a household (or at least parish and convent) name. Yet there was still no edition of any of the manuscript versions that adhered to modern standards of textual scholarship, even though the Early English Text Society had published its first volume in 1864, the Oxford English Dictionary was appearing regularly in fascicle, and diligent Victorian scholars had already edited many Middle English treatises. At the same time there were no real translations either, just those strange hybrids, "modernized versions."

Perhaps because of the success of Warrack's version, only one other version of a complete text, Long or Short, was published between 1902 and 1958: in 1927 the Benedictine Dom Roger Hudleston brought out in a Roman Catholic devotional series a version based on the Sloane Manuscript. This might seem superfluous, but Warrack's publisher, Methuen, had no religious affiliation and perhaps it was felt that Roman Catholic ownership rights over Julian needed reasserting. Hudleston also claimed that his version was closer than his predecessors' to the Sloane Manuscript itself: 
While adopting modern spelling throughout, the actual wording of the text has been kept considerably closer to that of the MS than in the editions of Miss Warrack or Father Collins, although really obsolete words have been abandoned in favour of the nearest modern equivalent. ${ }^{27}$

But his support for Sloane was not unqualified: his version is subtitled "edited from the MSS" (my emphasis), possibly because he cites some passages from the Short Text in his notes, and he ventured the cautious opinion that Sloane was "perhaps nearer to the original text" than the Paris Manuscript.

In 1958 Sister Maria Reynolds, who had worked on the Short and Long Texts for University of Liverpool dissertations, published a "partially modernized" version of the Short Text. ${ }^{28}$ She stressed the rhetorical aspect of Julian's prose, describing her as "the first English woman of letters," a term that some might consider inappropriate to the early fifteenth century as it suggests someone whose primary interest lies in professional writing. Possibly Christine de Pisan can be regarded as a "woman of letters," but surely not the anchoress Julian, who made no attempt to circulate her writings as far as we know or use them to seek patronage. In some ways this characterization of Julian has in the event had (quite unintended) consequences, possibly more harmful than others that are merely ludicrous.

In 1955 the Westminster Manuscript had been identified as containing extracts from the Long Text but again, instead of a scholarly edition of the Middle English, a modernized version was published in 1961. Of The Knowledge of Ourselves and of God, 
was made by James Walsh (like Tyrrell, a Jesuit priest) and Eric, later Edmund, Colledge (like Cressy and Collins, an Anglican convert to Roman Catholicism); the Anglo-Catholic firm Mowbrays published it complete with nihil obstat and imprimatur, to make assurance doubly sure. It was described as "completely modernized in punctuation and spelling, vocabulary and idiom" and emended with reference to earlier "editions" where the editors considered it necessary. ${ }^{29}$ It was therefore a long way from the original manuscript, the neglect of which until recently, given that it is the earliest witness to the Long Text, was extraordinary and may have been due to a distrust of medieval anthologies and compilations. It has now however been edited by Hugh Kempster, ${ }^{30}$ and his edition forms the basis of the text recently printed by Watson and Jenkins. ${ }^{31}$ It has also been transcribed and translated by Reynolds and Holloway. 32

In the same year Walsh published a new version of the Long Text, in the same series (Orchard Books) as Hudleston's. For this he used transcripts of the Sloane and Paris Manuscripts made by Sister Reynolds. He outlined his editorial policy as follows:

I have adopted Paris as the basis of my version, though I have never scrupled to substitute a reading from Sloane whenever this seemed superior, either linguistically or textually. My choice of readings has been governed largely by what appear to me to be the principles of Julian's spiritual theology. In point of 
fact, I began my version in the settled conviction that there is nothing unorthodox, nothing contrary to Catholic theology, in the Revelations. ${ }^{33}$

No doubt as a Jesuit Walsh was reacting against the use to which Tyrrell had tried to put Julian. Nonetheless, this combination of textual eclecticism with theological rigidity is hardly in the best interests of the text, though one is at least grateful for the editorial candor that makes his policy so clear.

In 1966, at a time when there was a strong counter-culture interest in mysticism of all sorts, Penguin published in its Penguin Classics series the first real translation of Julian into Modern English, as opposed to piecemeal modernizations. The translator, Clifton Wolters, was an Anglican priest who had spent most of his working life in Newcastle, in the (then) industrial North-East of England. This is perhaps reflected in the salutary remarks he makes in his introduction:

Very rarely do works improve by being translated. Julian is more obscure than is generally recognized. Perhaps this is due to the sort of gold-panning treatment she is subjected to by those on the look out for nuggets. Golden sentences there are in plenty, but in the process of isolating them a lot of very rich minerals are sieved away. It is more profitable to treat her as a coalmine and work the seams. The yield is greater and more rewarding. ${ }^{34}$ 
The resulting translation is very free, more of a paraphrase, and not always successful, notoriously so in the case of one of Julian's "nuggets." It renders the famous line, that in the Sloane Manuscript reads "al shall be wele and al shall be wele and al maner of thyng shal be wele," as "it is all going to be all right; it is all going to be all right; everything is going to be all right." This is at least a genuine attempt to render Julian into Modern English: the "modernizers" who simply keep "all shall be well" misrepresent her, for Middle English shal is not accurately rendered by Modern English shall. But unfortunately Wolters has not gained accuracy by sacrificing elegance, for shal does not primarily indicate futurity but rather obligation or necessity. Nonetheless, Wolters' version was immensely successful and was reprinted at least six times. (In 1998 Penguin replaced it with a translation of both the Short and the Long Texts by Elizabeth Spearing, who uses Glasscoe's edition of the Sloane Manuscript for the latter. ${ }^{35}$ )

Wolters had also based his translation on the Sloane Manuscript, "generally accepted as the most reliable of the extant versions." ${ }^{136}$ But it was not for another ten years that a scholarly edition of that manuscript appeared. The credit for that goes to Marion Glasscoe, who in 1976 published her edition with the title A Revelation of Love. ${ }^{37}$ The next year Frances Beer published an edition of the Short Text in the Middle English Texts series, while simultaneously Colledge and Walsh published their monumental edition of both the Short and Long Texts, claiming it as the "first critical presentation of the texts of the Revelations" 38 and using as their base manuscript for the Long Text not Sloane but Paris. At the same time the editors 
published a translation of their own edition, announcing, "Although numerous beginnings have been made on critical text--that is, editions of the original language, displaying and evaluating all the evidence--the task was only successfully completed this year when the present writers issued their edition," 39 and asserting that all previous translations (including Walsh's own) were now superseded.

This confidence was premature. Their privileging of the Paris Manuscript over Sloane has certainly not met with general approval, nor has their reason: that is, its superior preservation of Julian's (presumed) rhetorical skills--in some ways a legacy of the earlier emphasis on Julian as a "woman of letters." Their edition, though respected and still widely read and cited, has not become the "received version." Rather, it seems to have stimulated various re-editing projects, most notably led by Anna Maria Reynolds and Julia Bolton Holloway, on the one hand, and by Nicholas Watson and Jacqueline Jenkins, on the other. This activity must stem from more than mere dissatisfaction with the choice of base manuscript by Colledge and Walsh. Rather, in the late twentieth century the whole idea of a "definitive" and "critical" edition had become problematized. Constructing a stemma and using it to reconstruct an archetype as close as possible to the author's "original," closer than any of the presumably flawed and corrupted surviving witnesses, were no longer (and had not been for some time) unchallenged editorial methods. And there were always texts for which they were inappropriate.

In the case of Julian's Long Text the only two independent witnesses to the complete text, the Sloane and Paris Manuscripts, were both written down at least two 
hundred years after the composition dates of $A$ Revelation of Love. ${ }^{40}$ In addition, they sometimes disagree significantly. Some of these divergences may even be due to revision by the author herself for all we know. Nor does the only copy of the Short Text consistently support either manuscript when comparison is possible. Some would consider a definitive and convincing reconstruction of the "original version" of the Long Text is pretty much of an impossibility, and that any attempt to produce one would be permeated by subjective editorial judgment. And if ever a text has been at the mercy of editors, their prejudices, quirks, and hidden agendas, it is Julian's. ${ }^{41}$

But neither Watson and Jenkins, nor Reynolds and Holloway, in their different ways, could resist the temptation to attempt the impossible. The results are strikingly different: Watson and his fellow-editor have produced a radically conflated but meticulously documented text and Holloway and her fellow-editor an edition that is textually conservative but in many other respects highly speculative. Both projects deserve our respect, although one is put in mind of Gerald Manley Hopkins's comment on Milton: "The effect of studying masterpieces is to make me admire and do otherwise." The more prudent (or boring) among us continue to believe that what would be far more useful than further attempts at "critical editions" would be proper editions of the various witnesses.

We do have Beer's currently out-of-print edition of the Short Text, though it perhaps pays too much attention to the Long Text. We also have Glasscoe's edition of the Sloane Manuscript, whose unpretentious presentation belies its importance, but it still comes with an admittedly incomplete glossary and textual notes only. A later 
student edition of the Sloane Manuscript (with occasional emendations from Paris) by Georgia Ronan Crampton, who characterizes hers as "a conservative text," has a fuller glossary and ample explanatory notes. ${ }^{42}$ Yet a third student edition, edited by Denise Baker, this time based on the Paris Manuscript " $[b]$ ecause its language is closer to Modern English than that of the Sloane manuscripts," came out in 2005: this partly satisfies the need for an edition of Paris itself, rather than of Paris sometimes conflated with Sloane, as offered by Colledge and Walsh. ${ }^{43}$

At the other extreme, the 2006 edition of her complete oeuvre produced by Nicholas Watson and Jacqueline Jenkins was not presumably designed with students in mind. Theirs is a complete departure from earlier editions: admittedly "more interventionist and more speculative," it sets out to "establish a hybrid text that differs in many details from its predecessors." 44 Although their edition of the Long Text uses the Paris manuscript as its base text, it imports readings not only from Sloane but also, as it is self-confessedly "synthetic," the Amerherst Manuscript. ${ }^{45}$ The even pricier edition of Reynolds and Holloway "replicates the surviving manuscripts as closely as possible," 46 presenting diplomatic transcriptions of each witness. It even goes to the extent reproducing of the page rulings of the Westminster and Paris manuscripts and it keeps long " $\mathrm{s}$ " as well as thorn and yogh.

If over a decade ago I could associate Julian with a possibly childless Lady Macbeth, perhaps now she looks more like the old woman who lived in a shoe, who had so many children she (or we) did not know what to do. What more could be the 
objects of our textual desire? A wish-list might include a reprint, preferably in facsimile, of Cressy's rare edition of 1670 (available online through ChadwyckHealey's Early English Books Online service). Apart from its textual value it throws light on late-seventeenth century English Catholicism and its attitude towards medieval texts ${ }^{47}$ - and an edition of Sloane 3705 , a witness that has no intrinsic textual value, to serve a similar purpose for the eighteenth century: bad manuscripts do have certain virtues for those interested in the "sociology of texts."

And what of the translations? They can only be translations, not of "Julian's Revelations" but of a particular version. The existing translations, however, do preserve much valuable information about the reception of the Julian texts and the many ways in which they have been found useful by different readerships at different times. One would not wish to disparage what so many have found there over the last five hundred years, even if readers have mainly found what they wanted to find.

It is not been possible to discuss in detail the problems of translating the Julian texts into Modem English and in any case this would now be superfluous. ${ }^{48}$ Briefly, Modern English is not simply Middle English with different spelling and certain obsolete words replaced. Too much else is significantly different, though this is not always immediately obvious. Moreover it is no longer possible to bank on the general awareness or passive knowledge of archaic forms of English which prevailed, at least among the devout, fifty years ago when the Authorized and Douai versions of the Bible were still widely read, and the 1662 Book of Common Prayer in 
use. One would think it obvious that "modernized" versions are no longer viable, but unfortunately they continue to appear. One attempt, which had best remain unidentified, is readable enough but its editors are quite confused about the history of their text, wrongly claiming that the Paris Manuscript is the earliest, and that it contains the Short Text! The version is, unforgivably, based not on the Sloane Manuscript itself, but on Warrack's version of Sloane. A recent selection also bases itself on "Grace Warwick" (sic). ${ }^{49}$

There will however always be a place for translations for readers who cannot read Middle English. For those willing to attempt Julian's texts in their original forms, there is now a huge choice of editions with varying editorial philosophies and extensive glosses, annotations and/or glossaries. We could still use affordable editions with facing-page prose translations into Modern English that are not afraid to diverge quite markedly from the Middle English in order to render the linguistic nuances of the original. (Reynolds and Holloway provide modernizations, rather than translations, on the same page as her "quasi-facsimile" editions of Westminster, Paris, and Amherst. ${ }^{50}$ Watson and Jenkins consider, and reject, the provision of translations as such, instead preferring extensive notes and paraphrase. ${ }^{51}$ ) Such versions hardly sounds like potential best-sellers and indeed both Reynold's and Holloway's monumental edition and Watson's and Jenkins's are expensive (190 and 70 Euros respectively), putting them beyond the reach of students or even of most general readers. 
But Julian is not really a "popular" author, for all her current popularity. She certainly was not in the past, as the social history of her texts makes clear. Far more stands between modern readers and Julian that just the obsolescence of her own, or her scribes', language. She is often obscure and difficult and must be approached with all the resources of scholarship as well as with good intentions, for we still know too little about her and her texts. (It is chilling that some studies of her theology have been perfectly happy to base themselves on existing translations rather than the Middle English originals, a method that would be unthinkable in dealing with biblical or patristic texts.) Even the knowledge that is available, for instance about Middle English vocabulary and semantics, has not been fully exploited in the past to elucidate her meaning.

Furthermore, textual scholars have a duty to emphasize that our concept of "Julian of Norwich" can be no more than that of a group of texts of obscure and uncertain history, a view that should modify her current near-canonization. For instance, some Anglican dioceses now celebrate a Feast of Saint Julian on 8 May, quite an achievement for a shadowy figure of whom we know practically nothing except that she wrote at least two accounts of a series of visions--accounts that may or may not be accurately preserved in the various manuscripts, almost all written long after her death, the exact meaning of which we often do not understand. Such veneration places "Julian" in a very select group of authors of canonized texts, of which only four others spring to mind: Matthew, Mark, Luke and John. We need to 
ask ourselves whether such an apotheosis really does "Julian", and her readers, a service.

This is a revision of my article, "How many Children had Julian of Norwich?

Editions, Translations, and Versions of her Revelations", in Vox Mystica: Essays on

Medieval Mysticism, ed. Anne Clark Bartlett et al. (Cambridge: D. S. Brewer: 1995), pp.

27-39.

${ }^{1}$ See further Frances Beer, ed., Julian of Norwich's Revelations of Divine Love: The Shorter Version ed. from B.L. Add. MS 37790, Middle English Texts 8 (Heidelberg: Carl Winter, 1978), pp. 9-10.

${ }^{2}$ On the Amherst Manuscript as a whole, see now the excellent study by Marleen Cré, Vernacular Mysticism in the Charterhouse: A Study of London, British Library, MS Additional 37790, The Medieval Translator/ Traduire au Moyen Age 9 (Turnhout: Brepols, 2006).

${ }^{3}$ See further Edmund Colledge O.S.A. and James Walsh S.J., eds., A Book of Showings to the Anchoress Julian of Norwich: Part One: Introduction and the Short Text, Pontifical Institute of Medieval Studies Studies and Texts 36 (Toronto: 1978), pp. 9-10.

${ }^{4}$ Colledge and Walsh date it as mid-seventeenth century (A Book of Showings, p. 7), while Marion Glasscoe thinks it late-sixteenth or early-seventeenth century: see her 
"Visions and Revisions: A Further Look at the Manuscripts of Julian of Norwich,"

Studies in Bibliography 42 (1989): 105.

${ }^{5}$ Colledge and Walsh, eds., A Book of Showings, p. 8.

${ }^{6}$ Marion Glasscoe, ed., Julian of Norwich: A Revelation of Love (Exeter: University of Exeter Press, 1976), p. viii.

${ }^{7}$ On Cressy, see now Patricia C. Brückmann, “Cressy, Hugh Paulinus (1605-1674),” Oxford Dictionary of National Biography (Oxford: Oxford University Press, 2004)

[http://www.oxforddnb.com/view/article/6676, accessed 3 Jan 2008].

${ }^{8}$ XVI Revelations of Divine Love, published by R. F. S. Cressy (1670), sig. A3r.

${ }^{9}$ So-called after its most recent known location, St John's College, Upholland, Lancashire.

Its current whereabouts are unknown.

${ }^{10}$ George Hargreave Parker, ed., Sixteen Revelations of Divine Love, Made to a Devout Servant of Our Lord Called Mother Juliana (Leicester: Crossley, 1843), p. ii.

${ }^{11}$ Parker, ed., Sixteen Revelations of Divine Love, p. vii.

${ }_{12}$ Parker, ed., Sixteen Revelations of Divine Love, pp. vii-viii.

${ }^{13}$ Revelations of Divine Love, shewed to a devout Anchoress, by name, Mother Julian of

Norwich, with a preface by Henry Collins (London: T. Richardson and Sons, 1877), p. xiv.

${ }^{14}$ Collins, ed., Revelations of Divine Love, p. xiv.

${ }^{15}$ Grace Warwick [sic], ed., Revelations of Divine Love, $13^{\text {th }}$ edn. (London: Methuen, 1958), p. 
xiii.

${ }^{16}$ Warwick [sic], ed., Revelations of Divine Love, pp. xiv-xv.

${ }^{17}$ Warwick [sic], ed., Revelations of Divine Love, p. iv.

${ }^{18}$ XVI Revelations of Divine Love Shewed to Mother Juliana of Norwich 1373, with a

preface by George Tyrrell S.]. (London: Kegan Paul, Trench, Trübner, 1902).

${ }^{19}$ See further Nicholas Sagovsky, “Tyrrell, George (1861-1909),” Oxford Dictionary of

National Biography (Oxford: Oxford University Press, 2004)

[http://www.oxforddnb.com/view/article/36606, accessed 4 January 2008].

${ }^{20}$ Tyrrell, ed., XVI Revelations of Divine Love, pp. xiv-xv.

${ }^{21}$ See Georgia Ronan Crampton, ed., The Shewings of Julian of Norwich (Kalamazoo:

Medieval Institute, 1994), pp. 19-20.

${ }^{22}$ Comfortable Words for Christ's Lovers, transcribed and edited by Dundas Harford

(London: H. R. Allinson, 1911) p. 13.

${ }^{23}$ See Sister Anna Maria Reynolds, C.P., and Julia Bolton Holloway, eds., Julian of Norwich:

Showing of Love: Extant Texts and Translations, Biblioteche e Archivi 8 (Florence: SISMEL, 2001).

${ }^{24}$ All Shall Be Well: Selections from the Writings of the Lady Julian of Norwich A.D. 1373

(London, 1908), pp. iii-iv.

${ }^{25}$ All Shall Be Well, p. ix. The first contemplative Anglican community for women, the 
Society of the Love of God, located at Fairacres in Oxford, was not founded until 1906 or 1907.

${ }^{26}$ The Shewing of a Vision, being extracts from "Revelations of Divine Love" shewed to a devout anchoress by name Mother Julian of Norwich (London, 1915), pp. viii-ix.

${ }^{27}$ Dom Roger Hudleston, O.S.B., ed., Revelations of Divine Love, $2^{\text {nd }}$ ed. (Burns and Oates: London, 1952), p. viii.

${ }^{28}$ A Shewing of God's Love (London: Sheed and Ward, 1974)

${ }^{29}$ Eric Colledge and James Walsh, S.J., Of the Knowledge of Ourselves and of God: A

Fifteenth-Century Florilegium (London: Mowbrays, 1961), p. xviii.

${ }^{30}$ Hugh Kempster, "Julian of Norwich: The Westminster Text of A Revelation of Love," Mystics Quarterly 23 (1996): 177-245.

${ }^{31}$ Nicholas Watson and Jacqueline Jenkins, eds., The Writings of Julian of Norwich: A Vision Showed to a Devout Woman and A Revelation of Love, Medieval Women: Texts and Contexts 5 (Turnhout: Brepols, 2006).

${ }^{32}$ Reynolds and Holloway, eds., Julian of Norwich, Showing of Love, pp. 37-117, based on Reynolds's 1956 University of Liverpool thesis.

${ }^{33}$ The Revelations of Divine Love of Julian of Norwich, trans. J. Walsh, S.J. (London: Burns and Oates, 1961), p. vi.

${ }^{34}$ Julian of Norwich: Revelations of Divine Love, trans. Clifton Wolters (London: Penguin, 1966), p. 20. 
${ }^{35}$ Julian of Norwich: Revelations of Divine Love, trans. Elizabeth Spearing, intro. A. C.

Spearing (London: Penguin Books, 1998).

${ }^{36}$ Julian of Norwich, trans. Wolters, p. 14.

${ }^{37}$ Glasscoe, ed., Julian of Norwich: A Revelation of Love.

${ }^{38}$ Colledge and Walsh, eds., A Book of Showings, p. 196.

${ }^{39}$ Julian of Norwich: Showings, trans. Edmund Colledge, O.S.A. and James Walsh, S.J. (New York: Paulist, 1978), p. 17.

${ }^{40}$ The debate over the composition dates of the various Julian versions would furnish material for a separate article. See Nicholas Watson, "The Composition of Julian of Norwich's Revelation of Love," Speculum 68 (1993): 637-83.

${ }^{41}$ See further Glasscoe, "Visions and Revisions."

${ }^{42}$ Georgia Ronan Crampton, ed., The Shewings of Julian of Norwich (Kalamazoo: Medieval Institute, 1994, repr. 1996).

${ }^{43}$ Denise M. Baker, ed., The Showings of Julian of Norwich (New York: W. W. Norton, 2005). Although this is part of the Norton Critical Edition series, textual scholars would probably regard it as closer to a "variorum" than a "critical" edition.

${ }^{44}$ Watson and Jenkins, eds., The Writings of Julian of Norwich, p. $x$.

${ }^{45}$ Watson and Jenkins, eds., The Writings of Julian of Norwich, pp. 39-40.

${ }^{46}$ Julian of Norwich: Showing of Love, ed. Reynolds and Holloway, p. 6.

${ }^{47}$ Watson and Jenkins point out that Cressy's edition "is the most important document in 
the history of the work's reception and of perceptions of its author, fixing the image of Julian for centuries to come" (The Writings of Julian of Norwich, p. 16).

${ }^{48}$ See the discussion in Watson and Jenkins, eds., The Writings of Julian of Norwich, pp. 25-7.

${ }^{49}$ To be fair, the title page of the $13^{\text {th }}$ edition gives the translator's name as "Grace Warwick," though the "Note to the Thirteenth Edition" by P. Franklin Chambers correctly calls her "Grace Warrack of Edinburgh."

${ }^{50}$ Julian of Norwich, Showing of Love, ed. Reynolds and Holloway: the term "quasifacsimile" occurs on p. 495, while the blurb claims that "[t]he volume presents the manuscript texts, diplomatically transcribed."

${ }^{51}$ Watson and Jenkins, eds., The Writings of Julian of Norwich, pp. 25-6. 